\title{
Albanon
}

Revistë kulturore

\section{Zhvillimet urbane të qytetit të Elbasanit në periudha të ndryshme historike}

Zhuljeta Daja

Gjatë periudhës osmane në Elbasan dominon banesa me hajat. Banesa me hajat dallohet për kompozimin e shtrirë horizontal, për lidhjen e ngushtë me oborrin dhe natyrën në përgjithësi... Në Elbasan ka qenë ndërtuar edhe një tip banese që dallonte nga banesa e zakonshme me hajat, pasi ishte e ngritur nga trualli rreth 40-100 $\mathrm{cm}$. Pikërisht, ky tipar lokal i ka dhënë emërtimin karakteristik "dollmallije", d.m.th. e mbushur, ose "shtëpi Elbasani”. Kjo mënyrë ndërtimi, mund të jetë diktuar nga përmbytjet që vërshonin në qytet nga disa përrenj stinorë, megjithëkëtë, kjo zgjidhje tregon për një kulturë të mirë banimi. Veç kësaj, në Elbasan ka ekzistuar edhe banesa me çardak. Banesa me çardak në të gjithë ballin, është një zgjidhje e thjeshtë e këtij tipi banese.

\section{Hyrje}

Pushtimi osman solli ndryshime të dukshme në Shqipëri, që u reflektuan edhe në tiparet e reja si në shtrirjen dhe kompozimin urbanistik të qyteteve. Një shembull mjaft i dukshëm në këtë drejtim është qyteti i Elbasanit. Fillesa e qytetit të Elbasanit dhe peizazhit të ri urbanistik, i përket vitit 1466, kur sulltan Mehmeti II rindërtoi për një periudhë prej 25 ditësh, mbi gërmadhat e një qyteti të vjetër, kalanë që e quajti el-basan, që do të thotë "sundues $i$ vendit". ${ }^{1}$ Gjatë rindërtimit u ndoq me përpikmëri planimetria

1 Gjerak Karaiskaj, 5000 Vjet fortifikime në Shqipëri, Shtëpia Botuese "8 Nëntori"1981, f. 206. 
Porta e qytetit

(Porta e Kalasë), 1916.

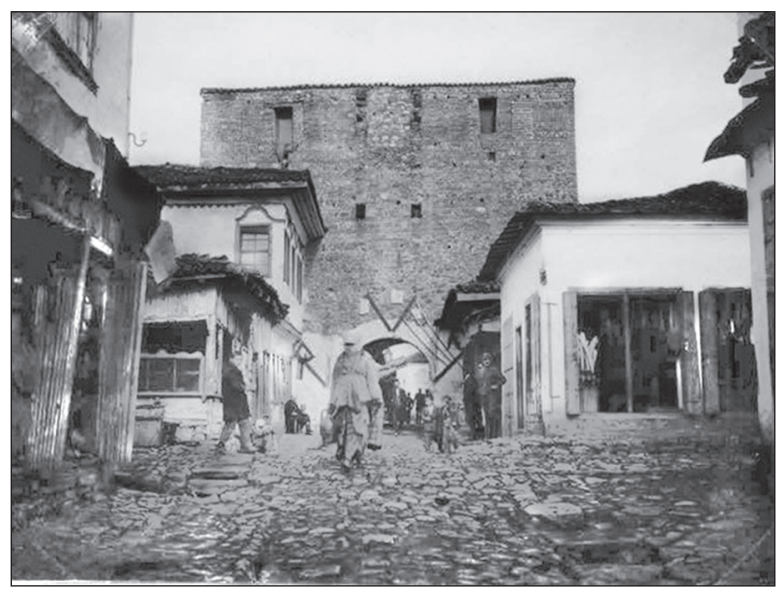

ekzistuese e një kalaje të rrënuar, të ndërtuar qysh në shek. IV të erës sonë, duke u shfrytëzuar traktet e mureve që ruheshin ende në këmbë1. Që nga ky moment, Elbasani do të marrë rëndësi të veçantë edhe për pozicionin e rëndësishëm gjeografiko-strategjik që kishte. Ai do të luajë një rol udhëheqës në planet ushtarake të Perandorisë, duke u kthyer njëkohësisht në një qendër të rëndësishme të myslimanizmit ${ }^{2}$. Në Kala, pas përfundimit të rindërtimit, u vendosën garnizone ushtarake, reparte marshimi gjithashtu edhe përfaqësuesit e pushtetit lokal së bashku me familjet e tyre. Në esencë, kjo përfaqësonte një popullim osman të Elbasanit ${ }^{3}$.

Shumë studiues janë përpjekur të analizojnë këtë periudhë në këndvështrime të ndryshme. Në fakt, asnjë nuk është ndalur në zhvillimet urbane. Edhe prof. dr. Ferit Duka, i cili ka trajtuar këto probleme, e ka bërë këtë vetëm për qytetin e Beratit ${ }^{4}$. Qëllimi i këtij punimi është të nxjerrë në pah ndryshimet që ka pësuar Elbasani në planin urbanistik gjatë periudhave të ndryshme historike, që nga rindërtimi i kalasë nga osmanët, deri më sot. Për këtë kemi shfrytëzuar një literaturë të gjerë historike, materiale origjinale (dokumente osmane) si dhe planet urbanistike të qytetit. Analiza përqendrohet kryesisht në elemente të tilla si: rrugët, lagjet, objektet fetare, banesat etj. Për të përmbushur këto objektiva, punimi është organizuar në nëntë çështje kryesore. Në çështjen e parë, jepet zhvillimi urban në periudhën osmane; në

1 Po aty.

2 Zheljaskova, A. Razprostranienie na islama vzapadno Balkanskite zemi pod osmanska vlast (XV-XVIII) Izdatelztvo na Belgarskata Akademija na Naukite. Sofje 1990, përkthimi në Institutin e Historisë, f. 91.

3 Po aty.

4 Gazeta Mapo, 2010, f.11. 


\section{Albanon}

Revistë kulturore

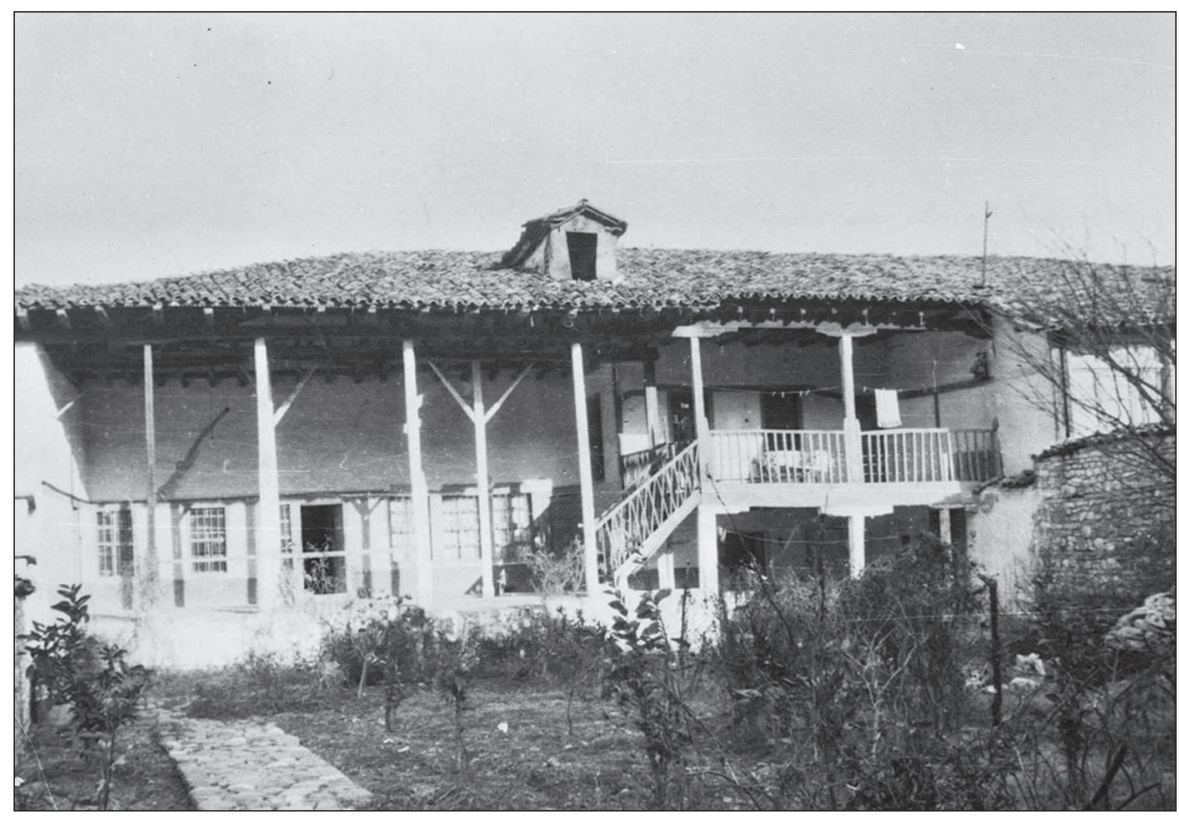

Shtëpia e vëllezërve Çiftja

çështjen e dytë flitet për lagjet si pjesë e strukturës urbane; në çështjen e tretë dhe të katërt trajtohen objektet e kultit islam dhe objektet e kultit të krishterë; në çështjen e pestë dhe të gjashtë flitet për pazarin, sheshet ndërtimet publike dhe banesat, në çështjen e shtatë ndalemi te zhvillimi urban gjatë shek. XX; në çështjen e tetë jepen disa tipare të zhvillimit urban në Elbasan në fillim të shek. XXI dhe përfundimet.

\section{Zhvillimi urban në periudhën osmane}

Qytetit të Elbasanit, që nga themelimi iu desh gati një shekull që të marrë formën e një qyteti me të gjitha tiparet. Pushimi i veprimeve luftarake, krijoi kushte në qytet për të ardhur një numër i madh fshatarësh, të cilët ikën nga timaret për t'i shpëtuar shfrytëzimit të spahinjve. Këta fshatarë merreshin krahas bujqësisë edhe me zejtari. Ardhja e këtyre banorëve të rinj, solli shtimin gradual të popullsisë brenda e jashtë mureve të kalasë ${ }^{1}$. Vendosja e popullsisë së ardhur jashtë mureve të kalasë, e bënte të domosdoshëm hartimin e një strukture të re urbanistike. Në kushtet konkrete, konceptimi urbanistik pëson një ndryshim thelbësor.

1 Zija Shkodra, Esnafet Shqiptare në shek. XV deri në shek. XX, Tiranë 1973, f. 26. 


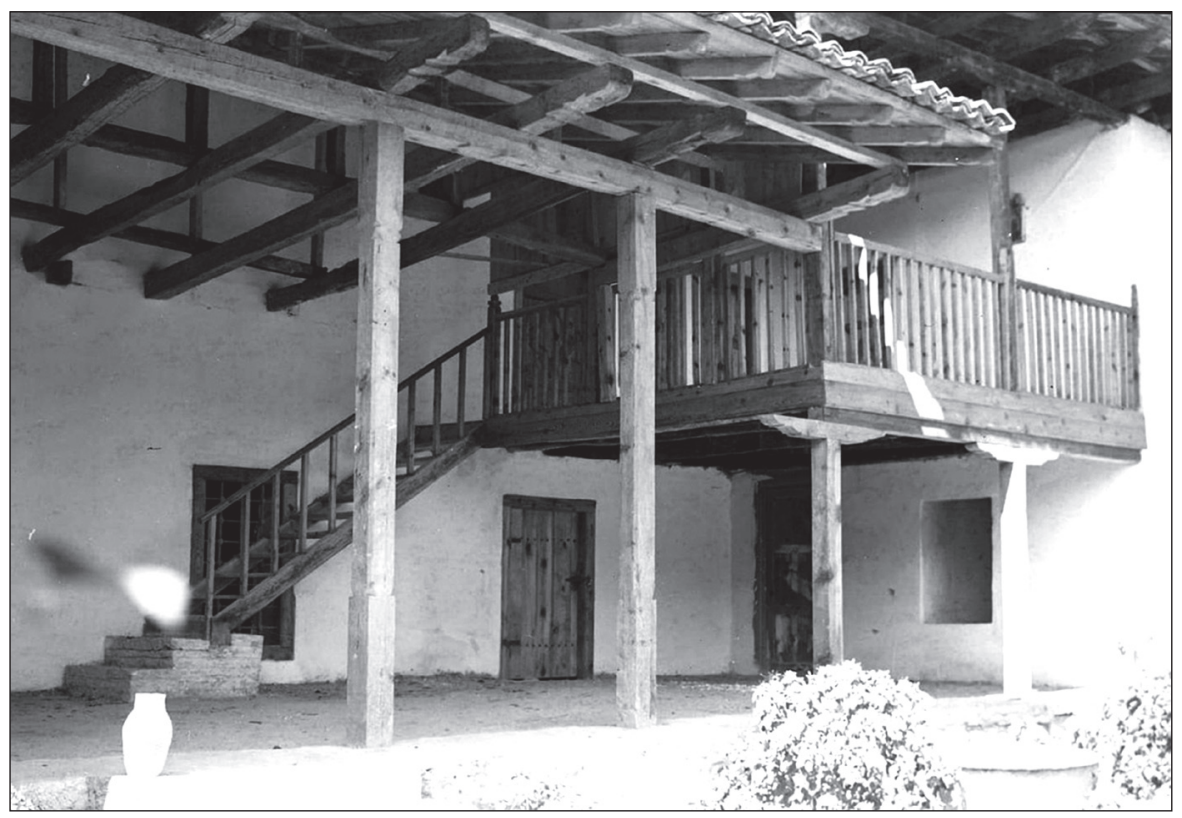

Shtëpi e familjes Duhanxhiu

Karakteristikën kryesore të strukturës urbanistike të Elbasanit, duke filluar që nga fillimi i shek. XV, e përbën lindja dhe zhvillimi i formacionit islamikooriental si komponent $\mathrm{i}$ rëndësishëm $\mathrm{i}$ ansamblit urban të kësaj kohe. Krijimi dhe zgjerimi i mëhallëve të reja myslimane si rezultat i islamizimit të popullsisë qytetare, do t’i jepte një pamje të re peizazhit urbanistik të qytetit. Qyteti i Elbasanit në fund të shek XVI, nga 806 shtëpi, 638 prej tyre i përkisnin elementit mysliman, shifër kjo e barabartë me afërsisht $79 \%$ të numrit të përgjithshëm ${ }^{1}$.

\section{Lagjet si pjesë e strukturës urbane}

Duke shqyrtuar dokumentacionin e kohës, rezulton se në vitin 1604 Elbasani ka pasur 40 mëhallë2. (Dokumenti i përket një protokolli të vendimeve të kadiut të qytetit, të vitit arab 1013). Megjithëse në protokoll këto quhen lagje, mundet që një pjesë e tyre të kenë qenë edhe rrugë (shën. i autorit). Në vazhdimësi, ne konstatojmë se i kemi të ruajtura një numër të konsiderueshëm të këtyre lagjeve. Nga analiza e shifrave të dhëna në regjistrat osmanë,

1 Petrika Thëngjilli, Shqiptarët midis lindjes dhe perëndimit, Fusha fetare, Tiranë, 2002, f. 18.

2 A.Q.SH, Fondi 32, dosja 39, fl. 65 


\section{AlBanon}

Revistë kulturore

rezulton se lagjet Kala, Haxhijas dhe Shën Koll ishin lagjet me popullsi të besimit ortodoks, kurse lagjet Ebu Bekri, Haznedare, Beqire, Spahikorre etj., kishin popullsi të besimit islam ${ }^{1}$. Ky raport i lagjeve në përbërjen fetare të popullsisë, është një argument në favor të rritjes së islamizimit të popullsisë në qytetin e Elbasanit. Interesant është fakti që brenda lagjeve, qofshin këto ortodokse apo myslimane, gjejmë “oaze” të besimeve të kundërta. Dukuria e mësipërme lidhet me tolerancën fetare që mbizotëronte në këtë qytet, si në gjithë Shqipërinë.

\section{Objektet e kultit islam}

Një element i rëndësishëm i strukturës urbane të qytetit të Elbasanit për periudhën fundi i shek. XIX dhe fillimi i shek. XX, u bënë objektet e kultit islamik si: xhamitë, mesxhidet, teqet etj. Këto objekte shërbyen si një faktor mjaft i rëndësishëm në procesin e islamizimit të popullsisë. Ndër më të vjetrat xhami në qytetin e Elbasanit përmendet xhamia e Fatihut, ndërtuar mbi kullën e hyrjes së Kalasë së qytetit në vitin 1466. Një fazë e re në ndërtimin e faltoreve islamike fillon pas pushtimit të vendit dhe lidhen me emrin e sulltan Bajazitit II (1481-1512). Në fund të shekullit $\mathrm{XV}$, për sunduesin osman duket se bëhet imperative kthimi i popullsisë në fenë islame. Mendohet që mjaft xhami të jenë dhuruar apo porositur nga sulltani, me qëllim që të ishin qendra të propagandimit të fesë islame në vitin 1492, kur ai ishte për një kohë të gjatë në Shqipëri² ${ }^{2}$ Nga shek. XV deri në shek XVI, sipas Evlia Çelebiut në Elbasan kishte 46 xhami dhe 20 mesxhide nëpër lagje ${ }^{3}$. Sipas Lef Nosit, në Elbasan janë ruajtur 30 xhami deri në vitet '30, listë të cilën e riprodhon edhe M. Kiel, 7 nga të cilat janë edhe në një përshkrim të Vilajetit të Manastirit nga Mehmet Teufik ${ }^{4}$. Ndër xhamitë më të përmendura edhe në pikëpamje arkitektonike kanë qenë: Xhamia e Ballies, e Agait, Nazireshës, etj. Xhamia e Ballies nga Çelebiu është emërtuar si xhamia e Hasan Ballizades 5 . Me kalimin e viteve çdo lagje kishte xhaminë e saj që shërbente për të kryer ritet islame dhe përhapjen e fesë islame. Të tilla ishin: Xhamia e Sofiumes (në veri-perëndim të kalasë), e Hamamit (në

\footnotetext{
1 A.Q.Sh, F nr 113/1

2 Aleksandër Meksi, Arkitektura e xhamive të Shqipërisë-Tiranë 2007.

3 Po aty.

4 Po aty, 57.

5 Po aty.
} 


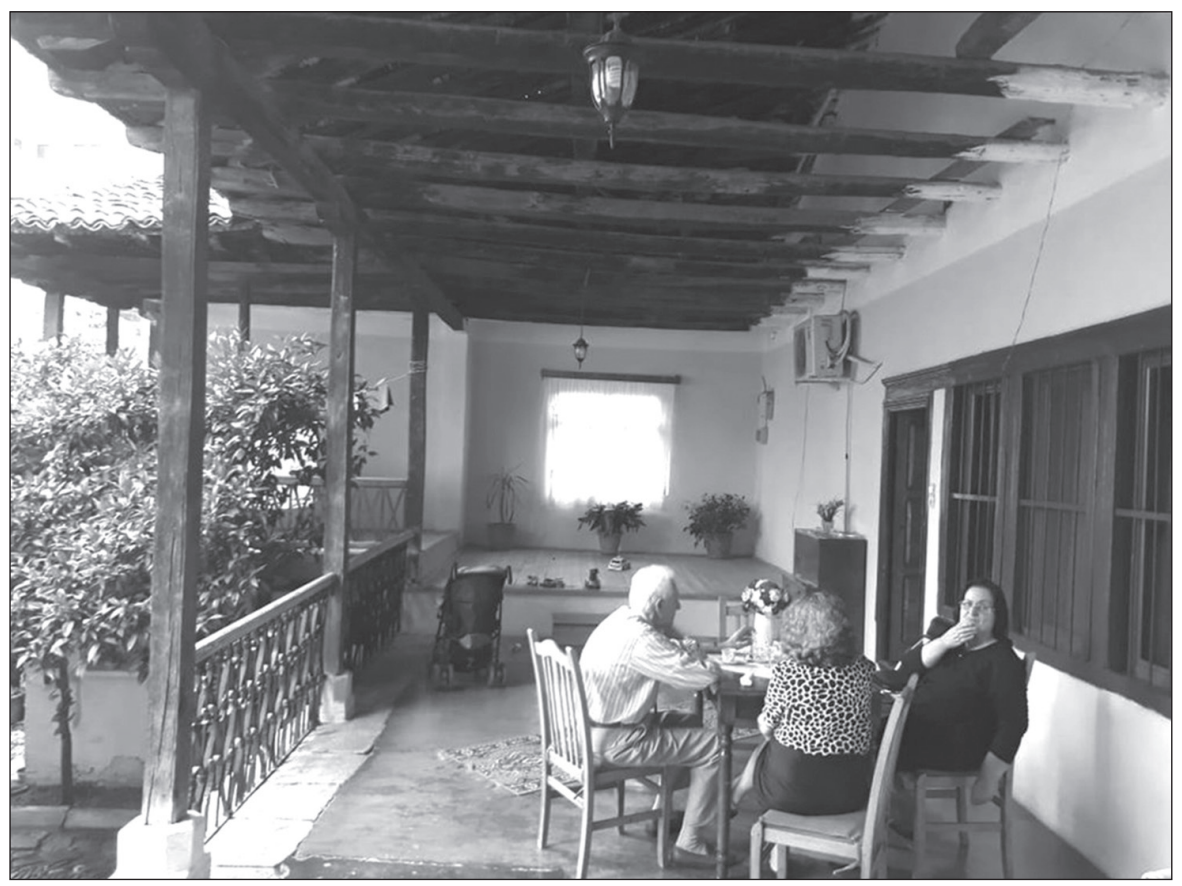

Pamje e sotme e shtëpisë së Sali Ramiz Qafmolla. Ndërtim i viteve 1840-1860.

lindje të kalasë), e Adil Beut (në perëndim të kalasë), e Hynqarit, xhamia Mbret (në qendër të kalasë), e Nazireshës, në pjesën jugore të qytetit, e Idarit (te tregu fshatar), e Tabakëve (te sheshi i Tabakëve), e Hasan Pashës (në lagjen "Alaedin”), e Haznedares (pranë shkollës "Ptoleme Xhuvani"), e Namazgjahut (te Selvitè), e Pashës, e lagjes "Daut Bej," e Zaranikës, e Axhemit, e Çaushllinjve, e lagjes "Budur Iskënder", e "Naskollit", e "Dylgjer Hyseinit", e "Haxhihasanit", e "Sulejmanies", e "Spahikorres", e "Haxhi Hafezzit", e "Bobolles", e "Ballies", e "Qoshes" dhe $e$ "Kalandries".

\section{Objektet e kultit të krishterë}

Nga analiza e dokumenteve të ndryshme, kemi konstatuar se në qytetin e Elbasanit në periudhën 1892-1908, krahas myslimanëve, kishte edhe të krishterë ortodoksë, të cilët ishin më të pakët në numër. Këta të krishterëortodoksë ishin vendosur në shumicë në lagjet "Kala", "Shën Koll", "Haxhias"

1 Shyqyri Demiri, Histori e shkurtër e trevës së Elbasanit, 2006, fq. 25. 


\section{Albanon}

Revistë kulturore

dhe "Sapuni". Veç lagjeve "Kala", "Shën Koll", "Sapuni” dhe "Haxhias", ku dominonte popullsia ortodokse, në lagjet e tjera prania e tyre është një element më i rrallë. E njëjta traditë vazhdon pothuajse edhe sot në përbërjen fetare të këtyre lagjeve. Në Elbasan në këtë periudhë ka pasur tri kisha, një në lagjen "Kala", në lagjen "Shën Koll" dhe "Haxhias".

Kisha e Shën Mërisë në lagjen "Kala” ka qenë nga më kryesoret në qytet. Fillesat i ka në shek. XVII. Në 11 nëntor 1819 kisha u dogj plotësisht. ${ }^{2}$ Në periudhën 1826-1833, filluan e përfunduan punimet për rindërtimin e saj. Kisha në pikëpamje ndërtimore, qoftë në planimetri apo vëllim, paraqet interes. Ajo është ndërtuar me gurë e tulla. Pikturat e kubesë janë realizuar në vitin 1859. E veçanta e saj qëndron tek ikonostasi i gdhendur nga 40 mjeshtra dibranë, që punuan për rreth dhjetë vite. Është i lyer me llak ngjyrë floriri. Kjo kishë shquhet për vlerat e saj arkitekturore. ${ }^{3}$

Në pjesën veriore të qytetit ndodhej kisha e Shën Thanasit. Kjo kishë ortodokse është ndërtuar në vitin 1846, fillimisht e ndërtuar në përmasa të vogla me materiale druri. Shërbente për kryerjen e ceremonive mortore të popullsisë ortodokse të qytetit. Pranë saj ndodheshin varrezat. Ceremonia e parë mortore është bërë në vitin 1846. Ajo është bërë për një qytetare të ardhur në Elbasan e të njohur me emrin Maria e Qyqes. ${ }^{4}$

Në pjesën jugore të qytetit ndodhej kisha e Shën Kollit. Nuk ka të dhëna dokumentare për mënyrën e ndërtimit dhe arkitekturën e saj. Ajo i përket periudhës së shek. XVII dhe shërbente për banorët e lagjes "Shën Koll". Pas viteve 1990 kisha u rindërtua plotësisht me iniciativën e popullsisë së lagjes dhe mbështetjen e Kishës Ortodokse. Përsa i përket arkitekturës së ndërtimit, vemë re një rritje cilësore në ndërtimin e kishave. Në ndërtim zbatohen tipe dhe konceptime arkitektonike e konstruktive më të zhvilluara. Si xhamitë ashtu edhe kishat ishin pjesë e zhvillimit urban të qytetit.

\section{Pazari, sheshet dhe ndërtimet publike}

Qendra kryesore e qytetit ishte pazari, i cili përfaqësonte një ansambël urbanistik më vete, të vendosur diku në qendër të qytetit. Brenda pazarit ishin të vendosur dyqanet me një ose dy kate, të ngjeshura me njëra-tjetrën

\footnotetext{
1 A.Q.SH.F nr 113/1 regj. Daimi e Jokllama, vitet1902-1904, d. 15, f.103,172, d.17. f.4.

2 Elbasani Enciklopedi, vep. e cit., f. 289.

3 Po aty.

4 Elbasani Enciklopedi..., vep. e cit., f.289.

5 Po aty, f.290.
} 
dhe të rreshtuara sipas zejeve, gjatë një rruge. Në Pazar kishin sektorin e tyre të veçantë edhe njësitë e shërbimeve si: hanet, mejhanet, mensat etj. ${ }^{1}$ Pjesë e rëndësishme e qytetit kanë qenë edhe hamamet (banjat publike). Sipas regjistrave të kadiut të qytetit në fund të shek. XIX- fillim i shek. XX, në qytetin e Elbasanit, ka pasur 4 hamame. ${ }^{2}$ Nga më kryesorët ka qenë Hamami $i$ Vjetër (Hamami i Atik) rreth të cilit u ngrit lagjja me të njëjtën emër. ${ }^{3} \mathrm{Ai}$ ndodhej në pjesën lindore të lagjes "Kala". Sot ai ruhet si objekt, madje i shpallur monument kulture, megjithë ndryshimet në ndërtim e destinacion.

Nga këto hane dilnin karvanet e kuajve të Elbasanit, Tiranës, Durrësit, etj., që ngarkoheshin me vaj, ullinj dhe mallra të tjera për t'u nisur pastaj për në Dibër, Korçë dhe Manastir. ${ }^{4}$

\section{Banesa}

Gjatë periudhës osmane në Elbasan dominon banesa me hajat. Banesa me hajat dallohet për kompozimin e shtrirë horizontal, për lidhjen e ngushtë me oborrin dhe natyrën në përgjithësi. Parapëlqimi i kësaj banese në Elbasan duhet i lidhur me karakterin e ekonomisë. Ekonomia qytetare ishte e pashkëputur nga prodhimi bujqësor. Sipërfaqet e gjera që kufizonin muret rrethuese të banesave, përbënin një faktor të rëndësishëm në ekonominë familjare. ${ }^{5} \mathrm{Në} \mathrm{literaturën} \mathrm{e} \mathrm{këshilluar,} \mathrm{pretendohet} \mathrm{se} \mathrm{kjo} \mathrm{banesë} \mathrm{është}$ ndërtuar deri në fillimin e gjysmës së dytë të shekullit XIX. ${ }^{6}$ Në fakt, ky tip banese u ndërtua edhe gjatë periudhës së fillimit të shek. XX e në vazhdim. Në Elbasan ka qenë ndërtuar edhe një tip banese që dallonte nga banesa e zakonshme me hajat, pasi ishte e ngritur nga trualli rreth $40-100 \mathrm{~cm}$. Pikërisht, ky tipar lokal i ka dhënë emërtimin karakteristik "dollmallije", d.m.th. e mbushur, ose "shtëpi Elbasani". Kjo mënyrë ndërtimi, mund të jetë diktuar nga përmbytjet që vërshonin në qytet nga disa përrenj stinorë, megjithëkëtë, kjo zgjidhje tregon për një kulturë të mirë banimi. ${ }^{7}$ Veç kësaj, në Elbasan ka ekzistuar edhe banesa me çardak. Banesa me çardak në të

1 Valentina Duka, Qytetet e Shqipërisë, 1912-1924, Toena, 1997, f.15.

2 A.Q.SH, F.nr.113/1 vitet 1892-1903, dosja 3-9.

3 Po aty.

4 Zija Shkodra, Qyteti shqiptar gjatë Rilindjes Kombëtare, botim i Akademisë së Shkencave, Tiranë 1984, f. 176.

5 Emin Riza, Banesa shqiptare gjatë mesjetës së vonë, Tiranë 1991, f. 114.

6 Po aty, 115.

7 Po aty. 


\section{AlBanon}

Revistë kulturore

gjithë ballin, është një zgjidhje e thjeshtë e këtij tipi banese. Kjo banesë është ndërtuar në lagjen "Kala" të qytetit, pra brenda ansamblit që rrethohet nga muret rrethuese të fortifikimit. Skema kompozicionale është e thjeshtë, përbëhet nga hajati dhe çardaku. Këto dy mjedise janë në katin përdhe dhe në katin e dytë. Një bllok i thjeshtë shkallësh druri, lidh të dyja katet. Muret anësore të ndërtimit zgjaten përpara, duke mbyllur vëllimet e hajatit dhe çardakut. Shtëpia e zjarrit është me përmasa të mëdha. Me interes është krijimi i një platforme të padjegshme pranë vendit të zjarrit. Në çardak, përkundrejt shkallëve, është ndërtuar qoshku'. Shembull tipik në këtë drejtim është shtëpia e Sejdinit (sot Muzeu Etnografik i qytetit).

\section{Zhvillimi urban gjatë shek. XX}

Gjatë shek. XX, tri kanë qenë periudhat gjatë të cilave zhvillimi urban ka pësuar ndryshime të dukshme në qytetin e Elbasanit. Në periudhën e viteve 1912-1924, menjëherë pas Shpalljes së Pavarësisë nuk pati ndryshime të ndjeshme në aspektin e urbanistikës. Në përgjithësi u ruajt po ajo frymë e trashëguar nga e kaluara otomane. Pazari në qender, objektet e kultit ishin ato të ndërtuara gjatë sundimit osman, po ai organizim administrativ dhe ato tipe banesash (me hajat dhe dollmallije). Periudha e viteve 1924-1943, shënon një moment tjetër të rëndësishëm në ndryshimet urbanistike të qytetit. Kjo periudhë lidhet me sundimin e Ahmet Zogut dhe pushtimin italian nё Shqipëri. Duke analizuar zhvillimin urban vemë re se, kemi ndikim të dukshëm të influencës italiane. Italianët për të ndjekur dhe orientuar zhvillimet urbanistike në Shqipëri kishin ngritur zyrën qendrore të ndërtimit dhe urbanistikës.

Zyra urbanistike hartoi planin për modernizimin e qyteteve të Shqipërisë midis të cilëve edhe planin urbanistik për Elbasanin. Ky projekt që u miratua në vitin 1940 lidhej në mënyrë organike me atë të fundviteve '20. Brenda këtij plani gjejmë të artikuluara nyjet më të rëndësishme që ishin të lidhura me njëra-tjetrën (riorganizimi dhe sistemimi i rrugëve si dhe funksionimi urban i tyre, krijimi i një boshti qendror nga spitali në veri dhe varrezat në jug). Një tjetër element i planit ishte çlirimi i kalasë antike nga ndërtimet jashtë murit, realizimi i një sistemi lulishtesh të lidhura me zinxhirë të verdhë për të nxjerrë në pah vlerat monumentale të saj. Kalaja duhej të harmonizohej në vazhdimësi me ndërtesat dhe rrugët rreth saj. Objektiv i planit rregullues ishte edhe rregullimi i qendrës politike administrative pranë bashkisë (1926)

Po aty. 
dhe ndërtimi i qendrave të tjera rezidenciale dhe mikpritëse të qytetit. ${ }^{1}$

Skema urbane e këtij plani përcaktohet nga pozita gjeografike ku është ndërtuar qyteti i Elbasanit. Qyteti ishte konceptuar në formën e një amfiteatri te madh, e përforcuar kjo nga elementet natyrale të kodrave me ullishta, elementet e infrastrukturës, si rrugët, urat, dalja dhe hyrja në qytet. Qyteti ishte i ndarë në kuadrate. Pjesa më e madhe e ndërtesave parashikohej njëfamiljare, ndërsa ato kolektive mungojnë. Në planimetrinë e qytetit lexohen qartë: banesat e ndëruara buzë rruge me lartësi të përcaktuar, gjelbërimi publik dhe privat, institucionet fetare, tregtare dhe administrative në qendër. Njëkohësisht përcaktoheshin arkitektura e banesave, lloji i mbulesës dhe katet e ndërtesave. Zhvillimi urban i qytetit në vazhdim tregon se ky plan nuk është zbatuar. ${ }^{2}$

Pas çlirimit të vendit, në vitin 1944, Partia Komuniste e orientoi Shqipërinë nga modeli sovjetik i zhvillimit. Disa parime marksiste mbeteshin themelore. Planifikimi i centralizuar i ekonomisë duhej të ndiqte modelin sovjetik. ${ }^{3}$ Këto parime do të ndiqeshin edhe në zhvillimin urban. Që në vitin 1947, gjatë miratimit të planeve rregulluese të qyteteve në Ministrinë e Ndërtimit thuhej se: "Në Shqipëri para okupacionit nuk ka pasur ligje urbanistike, por pjesërisht ligji i Bashkive ka pasur disa nene mbi planet rregulluese të qyteteve. Por ligji i periudhës së okupacionit fashist, ka qenë një tentativë e parë për një legjislacion urbanistik, por ky ka qenë bërë me qëllim për të përqendruar të gjithë aktivitetin urbanistik në duart e tyre dhe mban vulën e okupacionit dhe të politikës fashiste në Shqipëri. Këto ligje me vendimin e Kuvendit Popullor duhet të abrogohen e bashkë me to edhe planet rregulluese të qyteteve $e^{4}$."

Për të paraprirë zhvillimin urban sipas një modeli të ri me vendim të Këshillit të Ministrave u vendos të ndërtohen banesa kolektive me apartamente me sipërfaqe që varionte nga 29 deri në 50 metra katrore. Ky vendim ndaloi ndërtimet vetjake, pasi prishnin bukuritë e rrugëve e vendeve ku do të ndërtoheshin. ${ }^{5}$

Sot këto godina janë të pranishme në të dy rrugët ku u ndërtuan gjatë viteve

1 Adriana Maria Giusti, Albania e Architettura e Citta, 1925-1939, Maschietto Editore, Firenze, 2006, f. 76.

2 Bashkia Elbasan, Detyra e projektimit për planin e përgjithshem rregullues të Bashkisë Elbasan, Elbasan, qershor 2005, f. 129.

3 Edwin Jacques, Shqiptarët, Historia e popullit shqiptar nga lashtësia deri në ditëte sotme, Tiranë, 1995, f. 486.

4 A.Q.Sh, Fondi i Ministrisë së Ndërtimit, nr 899 dosja 894, f. 4.

5 Po aty. 


\section{Albanon}

Revistë kulturore

1960-70, bulevardi kryesor dhe rruga që të shpie tek ish-shkolla Pedagogjike. Ato janë simbol i periudhës së ndërtimit socialist në vendin tonë. Gjatë fundit të viteve '60, në valën e revolucionit Kulturor Kinez, Shqipëria futi një sërë politikash të reja. Lufta e pamëshireshme e Partisë kundër fesë e arriti kulmin me mbylljen e objekteve të kultit, kthimin e tyre në qendra kulture, sportive, teatro dhe magazina. ${ }^{1}$ Kjo ishte një masakër që iu bë historisë urbane të qytetit. Plani rregullues i kësaj periudhe nuk kurseu as pazarin në qendër së bashku me xhamitë. Në vend të pazarit karakteristik të periudhës osmane dhe italiane u ndërtuan Hotel Skampa, pallati i sportit, u krijua një sipërfaqe e madhe e gjelbëruar etj. Në vitet '70 pjesë e zhvillimit urban është edhe ndërtimi i Kompleksit Metalurgjik në luginën e lumit Shkumbin me ndihmën e Republikës Kineze.

Në vitet 1980 është hartuar një plan tjetër rregullues i qytetit nga Instituti i Studimeve dhe Projektimeve Urbane, miratuar në vitin 1983, plan me një perspektivë kohore deri në 20 vjet. Ai ishte hartuar mbi parimet e ekonomisë së centralizuar dhe të pronës shtetërore. Reth vitit 1988 zona e parashikuar për banim po plotësohej me ndërtesa kolektive 5-6 katëshe të cilat konturuan rrugët e qytetit që ishin planifikuar për ndërtime. E tillë qe rruga nga bashkia deri tek unaza jugore. Edhe ky bllok ndërtimesh nuk paraqet ndonjë vlerë të veçantë arkitektonike, veçse periudhën kur janë ndërtuar. Brenda këtyre blloqeve të banimit ishin parashikuar të ndërtoheshin shkolla, çerdhe, parqe lojrash për fëmijë, mjedise shlodhëse për të rritur, por që nuk u realizuan. Vitet ' 80 u shoqëruan me një krizë të thellë ekonomike gjë që ndikoi në mosrealizimin e projektit të viteve ' 80 .

\section{Disa tipare të zhvillimit urban në Elbasan në fillim të shek. XXI}

Pas viteve 1990 krahas zhvillimeve të reja politike kemi edhe ndryshime në zhvillimin urban të qytetit. Por cilat kanë qenë shkaqet e ndryshimeve urbane, vlerësuar në fillim të shek. XXI. Në fund të shek. XX e fillim të shek. XXI pati ndryshime të ndjeshme politike. Reformat e kryera mundësuan kalimin nga prona e përbashkët në pronën private, nga ekonomia e centralizuar në atë të tregut, u lejua feja dhe u respektua liria e besimit etj. Pas viteve '90, Elbasani pati ndryshime edhe në drejtim të urbanizimit, si pasojë e lëvizjes së lirë të popullsisë. Si rezultat i rritjes demografike, në Elbasan u bënë shumë ndërtime. Këto ndërtime shpeshherë janë bërë pa leje nga zyrat përkatëse,

1 Miranda Vickers, Shqiptarët, një histori moderne, Bota Shqiptare, Tiranë, 2008, f. 304. 
pa respektuar rregullat urbanistike dhe në mjaft raste duke mos u përshtatur me mjedisin përreth. Jo vetëm banorët e ardhur, por edhe vetë qytetarët e ndjenin nevojën për rritjen e sipërfaqes së banimit. Prej shumë vitesh ata jetonin në apartamente me sipërfaqe mjaft të vogla. Pas viteve'90, për shkak të faktorëve të mësipërm, Elbasani përjetoi valën e urbanizimit më të madh në histori, për këtë arsye u bë i domosdoshëm hartimi i planit të ri rregullues për qytetin. Zyra e urbanistikës pranë Bashkisë, në bashkëpunim me një studio projektimi italiane, paraqitën në vitin 2005 planin e ri rregullues të qytetit.

\section{Përfundime}

Pas një studimi të hollësishëm të zhvillimeve urbane në qytetin e Elbasanit, nga themelimi (1466) deri në fund të shek. XIX shohim që kemi një ndikim otoman shumë të madh. Ky ndikim padyshim kushtëzohet nga pushtimi i gjatë osman në vendin tonë. Ndikimet janë të pranishme në konfigurimin e mëhallëve (lagjeve), në pjesën më të madhe me popullsi myslimane, në ndërtimet e objekteve të kultit islam, banesave etj.

Pas Shpalljes së Pavarësisë ka patur tendencë për t'u larguar nga ndikimi otoman në zhvillimin urban. Kjo u vu re sidomos në periudhën e pushtimit italian. Banesa të reja sipas stilit europian u dukën në qytetin e Elbasanit. Projekti italian nëse do të zbatohej deri në fund, do të ndryshonte rrënjësisht zhvillimin urban, sidomos në vitet 1925 -1943.

Periudha komuniste ishte një tjetër moment $\mathrm{i}$ rëndësishëm që ndikoi në zhvillimin urban. Në këtë kohë çdo gjë u ndërtua sipas orientimeve marksiste-leniniste dhe mbështetur mbi pronën e përbashkët. Banesa kolektive ishte elementi më i dukshëm në ndërtim. Pas viteve 1990 zhvillimi urban u karakterizua nga kaosi dhe mungesa e një plani zhvillimor urban. Në vitin 2005 bashkia e qytetit ka miratuar planin e ri urbanistik, i cili është mbështetur mbi disa parime ekonomike dhe sociale të qytetit. Ky plan ka si qëllim të verë mbi baza ligjore ndërtimin dhe t’i japë qytetit një pamje tërheqëse dhe funksionale 